\title{
Francis Bacon and Jacobean Legitimation
}

\author{
José María Rodríguez García \\ Universidade da Coruña
}

\begin{abstract}
Francis Bacon (1561-1626) maintained a lifelong interest in the institutional implementation of experimental science. What changed over the years were the rhetorical strategies employed to give this project legitimacy. I systematize those changes by dividing Bacon's works into three groups according to three criteria: what rite of officialization is enacted in each text (e.g., conversion, fatherly generation, royal delegation); who the inscribed addressee is (e.g., an imagined audience of sympathetic disciples, the monarch, posterity); and what the status is of the invoked philosophical, religious, and political authorities. In this manner, I isolate three distinct versions of Bacon's rhetoric of legitimation.
\end{abstract}

\section{Charting Legitimation.}

Throughout his writing career Francis Bacon struggled to devise a feasible institutionalizing path for the sponsoring of the new utlitarian science and the political enfranchisement of its practitioners. By path I mean a succession of choices and actions geared toward the same end through the cooperative effort of a community of individuals. The one work in which Bacon outlines step by step the foundational moments that constitute a path is the New Atlantis (1623), an uncharacteristic Renaissance utopia precisely because an equal amount of attention is given to the articulation of those steps in a temporal sequence and to a description of the main features of the society in question. 
Before the practices that characterize a new society become institutionalized, they must acquire sufficient legitimacy by appealing to interest groups that articulate such practices in their discourse as an aspiration of their own or as an accepted deviation. In fact, the processes of legitimation and institutionalization usually run parallel to each other. Institutionalization does to day-to-day practice what the legitimation of a new idea does to a community structured according to a given consensus. Pierre Bourdieu, whose insights into the process of symbolic production in rigidly hierarchized political systems have strongly influenced my thinking on institutions, acknowledges as much when he writes that "an act of institution ... represents a form of officialization and legitimation" (Language and Symbolic Power 173).

Timothy Murray has also outlined a comparison between Habermas' and Bacon's respective notions of legitimation. He rightly points out that Habermas' explanation of how an ideology of reform is produced is adumbrated in Bacon's major treatises: a symbolic producer notices a collectively felt need for change, which he interprets subjectively according to his own aspirations yet undertaking such an interpretation in seemingly rational terms - in Bacon's case, by means of inductive reasoning and the production of utilitarian works (Murray 9). ${ }^{1}$ If the symbolic producer is to gather enough support for his program, he has to make a dominant group acknowledge (as Bacon tries to do with the monarchy, represented by James I) that idiosyncratic program as an objective answer to the demands of necessity. ${ }^{2}$ Only under these conditions can the institutionalizing process get under way.

Bacon knew how important it was to create one such climate of opinion; hence his continual cultivation throughout his career of the dedication, the prologue, the public oration, and other short forms conventionally used in the Renaissance to connect a work to the larger social context in which it was created and which it meant to influence. These shorter pieces can be divided into two groups: the posthumously published orations and prefaces (which connect Bacon's project to an imagined community of fellow scientists), and the dedications and prefaces introducing Of the Advancement and The New Organon (which seek the patronage of James I in the realization of the reforms outlined in the two treatises). As it is his last work, in the New Atlantis Bacon recapitulates, expands, and modifies many of the strategies of legitimation that he had employed in his earlier works. I anchor my argument on legitimation precisely upon this slim yet highly constructed corpus of prefaces, orations, and short fictions. Only there can we trace Bacon's changing construction of accepted pragmatic situations with which to advance his otherwise subversive ideas. I proceed to examine one such situation in an early text by Bacon to illustrate this point and lead my argument into a definition of legitimation applicable to his project.

In the Introductory Narrative of the posthumously published The Refutation of Philosophies (1607), a friend tells Bacon that he has just returned from a trip to Paris, where he had listened to a public oration on the need to de-Aristotelianize and deChristianize both scientific research and university education. The friend emphasizes the somehow clandestine yet by no means revolutionary nature of the event: "There were some fifty men ... all bearing the stamp of dignity and probity ... among them officers of state, senators, distinguished churchmen, people from all ranks of life, and foreigners from 
various nations" (Farrington The Philosophy 104). Throughout his writings Bacon repeats such allusions to groups that, while performing services for the monarchy, lived a life of inner exile and nonviolent dissent, and were perhaps ready to adhere to an institutional program that would enfranchise both the mechanical arts and the emerging class that practiced them.

Some individual groups not unlike the one described by Bacon have been identified by intellectual historians, e.g., Mark H. Curtis' underemployed or "alienated intellectuals" of Tudor and Stuart England; Hugh Kearney's self-educated artisan mechanics (a group Bacon mentions in the Paresceve [1620]); Christopher Hill's semiclandestine London astronomers and physicians; and Robert Kargon's atomistic philosophers of the Northumberland circle. ${ }^{3}$ I will not argue that Bacon knew what each group desired or that he intended to satisfy their desires; rather, I will focus on his assumption that a new ground was being sought from different quarters on which to found what Bacon calls a new "correspondentia ingeniorum et mentium" and a "legitimus consensus." Such a consensus could be induced if a method should be devised that were universally intelligible and used a form of empirical proof as the only standard of authenticity and truth. The necessity of one such method is suggested as early as in Bacon's first work, The Masculine Birth of Time (1603; publ. 1653), where induction-based certainty is figured as "trust":

Do you really think it is easy to provide the favorable conditions required for the legitimate passing on of knowledge [Lat. modus legitimus scientiae tradendae]? The method must be mild and afford no occasion of error. It must have in it an inherent power to inspire trust [Lat. vis insita et innata ad fidem conciliandam] and a vital principle which will stand against the ravages of time, so that the tradition of science may mature and spread like some lively vigorous vine. (The Philosophy 62; Works 7.17; English trans. emended)

To be sure, Bacon was all too quick to reduce the aspirations of other groups to the twofold objective of his program, i.e., to make utilitarian progress the end of all political associations, and empirical evidence the standard of truth. In the process of doing just this he inevitably mystified his own project as well as its context (note the similarity in wording between his phrase "ad fidem conciliandam" and the post-Reformation project of a consensus fidelium), but the guiding idea of arriving at a new consensus remained unaltered.

In fact, the notion of consensus or peaceful agreement is central to theories of legitimation, as is the rhetoric of persuasion used to bring about such an agreement. Bourdieu, for whom symbolic practices can in time alter even a very conservative political space, argues that the process of legitimating a new philosophy consists in the progressive acceptance of certain practices and ideas in the public domain without their being perceived as disturbing the larger social order. Bourdieu is especially interested in how an unsanctioned program comes to acquire the necessary legitimacy to become institutionalized and even hegemonic. ${ }^{6}$ Bourdieu's notion of the legitimation process revolves around the ability of the advocates of the new set of practices to induce trust in the communities they profess to serve, to communicate uninterruptedly with those same 
communities in understandable terms, and to sublimate their own self-interest as an emerging class into the promise of carrying out an interest-free project.

The issues of trust, communicative competence, and continuity v. change appear very prominently in Bacon's early writings. For example, in Thoughts and Conclusions (1607; publ. 1653) he expresses his frustration at the fact that at Oxford and Cambridge a student's departure from "the works of certain authorities" is still construed as being "disturbing and revolutionary." According to Bacon, the practice or study of any type of rational empiricism can be considered by many as an act of political sedition or religious heresy. He thus argues for using different criteria of validity to judge the legitimacy of political and scientific endeavors:

In politics even improvements are suspect on account of their power to disturb, for civil affairs rest on authority, assent, reputation, opinion [Lat. authoritas, consensus, fama, opinio], not on demonstration and on truth [demonstratio et veritas]. But in the arts and sciences, as in mining for minerals, there ought everywhere to be the bustle of new works and further progress. The distinction is right and necessary. (Farrington The Philosophy 79; Works 7.110; English trans. emended) ${ }^{7}$

The legitimation of the new science by works alone does not suffice; the production of those works must be accompanied by an assurance that, rather than undermining the legitimacy of the ruling political power, it somehow reinforces it. Hence Bacon's depiction of the teaching of science as the love of a father for his son; of the production of works as the fruits of a "chaste and legitimate marriage" [Lat. castum et legitimum connubium] (The Philosophy 72; Works 7.31-32); of the research into causes and effects as a Solomonic worship of God's creative powers; and of the institutional incorporation of the scientist into the state apparatuses as the fulfillment of a calling to serve the monarch and the realm.

Bacon never ceased to insist that, from the standpoint of epistemology, the long-lasting legitimacy of empiricist science rested not upon the authority of ancient texts but upon its ability to produce works that would appeal to the human instinct for material comfort and self-perpetuation (Valerius Terminus [Works 6.135]). ${ }^{8}$ The problem with this argument was that such works could not be produced overnight and that the overall project might be construed as being inimical to the established social order. Consequently, Bacon devotes a considerable portion of his writings to designing an institutional path for science that incorporates features of the patriarchal family, the Solomonic monarchy, and the Christian church. ${ }^{9}$ In point of fact, he had at his disposal, in the influential writings of the Elizabethan theologian, Richard Hooker, an analogical framework that linked together the offices of father, priest, governor, king, and God. In the Second Book of The Laws of Ecclesiastical Polity (1593), Hooker lays out two main tenets of his political theory, namely, that "all men have ever been taken as lords and lawful kings in their own homes," and that in a "politic society" an individual can acquire this type of "lawful power" only by "consent of men, or immediate appointment of God." Yet Hooker obscures the possibility of a government by consent at the end of the same paragraph, where in the syntactic unfolding of a single subordinate sentence, all four fatherly figures merge into one: 
Which is also (as it seemeth) the reason why the name of Father continued still in them, who of fathers were made rulers; as also the ancient custom of governors to do as Melchisedec, and being kings to exercise the office of priests, which fathers did at the first, grew perhaps by the same occasion. $(191)^{10}$

Although Bacon does not hierarchize authority in exactly the same way as Hooker, his avowed plea for implementing a socio-political regime that enfranchises individual citizens according primarily to merit and utility (what he calls his "conscientia meriti" [Works $6.450]$ ) is often undermined by the providential religious rhetoric that he uses to lend it legitimacy. ${ }^{11}$ In devising his own legitimating rhetoric, Bacon oscillates between his ideal of arriving at a "legitimate consensus" based on "legitimate induction" (in Hooker's terminology, a "lawful consent"), and his constant recourse to the more widely spread phenomenon of patrilinearity, which Bourdieu considers as well a "rite of legitimation."12

Significantly, in the New Atlantis Bacon depicts an ideal commonwealth, Bensalem, where the most respected individuals are all fatherly figures: King Solamona (its founding father), the Fathers of Salomon's House (the ruling elite class of scientists), the Tirsans or prolific patriarchs of an extended family, and the governor-priest. Furthermore, Bacon imagines in the New Atlantis that the Great Instauration of the sciences will take place without disrupting church history and dogma, and without being disturbed by it. Instead, the Instauration will be carried out by following to the letter the promise of Solomon's early prophecies of material comfort.

In Bacon's writings, the human creation of a new political order based upon a new type of science is often enveloped in the guise of a divinely ordained plan (announced prophetically by Moses, Daniel, or Solomon), or placed under the imagined patronage of James I, who himself is presented as the English Solomon. ${ }^{13}$ This rhetorical construction was in keeping with James' own self-construction as the establisher of a pax perpetua in Britain, as becomes evident in Lancelot Andrews' The Peace-Maker, or Great Brittanies Blessing (1619), of which James himself may have written small portions: "Let England (the seat of our Solomon) rejoice in her happy government ... and she that can set peace with others, let her enjoy it herself. We live in Beth-salem, the house of peace, then let us sing this song of peace, Beati Pacifici" (qtd. in Willson 271). ${ }^{14}$ Since medieval times Solomon had been construed as the auctor of peace and the auctor of wisdom, precisely the two signal achievements with which Bacon endows Bensalem's prophet-king, Solamona, in the New Atlantis. ${ }^{15}$

\section{Bacon's Three Narratives of Institutionalizing.}

Bacon's rhetoric of legitimation evolved throughout his writing career from a vehement refutation of the inherited theocentric and aristocratic forms of authority to a compromise of sorts with the fatherly authority of god and monarch. Not surprisingly, this development parallels Bacon's own political career, from his relative marginalization by Elizabeth (who for almost twenty years refused to confer upon him a public office) to his promotion by James I to the highest-ranking offices in the realm (appointed Solicitor-General in 1607, 
Lord Keeper in 1617, and Lord Chancellor in 1618). Since I will make frequent references to this parallel development in the remainder of this essay, I now proceed to outline the three different versions of Bacon's plotting of a legitimate institutionalizing path.

Bacon's first version or narrative is comprised of four very short writings originally written in Latin: The Masculine Birth of Time [Temporis partus masculus] (1603), the Preface for the unwritten Of the Interpretation of Nature [De Interpretatione Naturae Proemium] (1603), Thoughts and Conclusions [Cogitata et visa] (1607), and The Refutation of Philosophies [Redargutio philosophiarum] (1608). I designate these texts collectively as Bacon's pseudo-autobiographies because in them a first-person voice of what appears to be a Baconian philosopher adopts a protagonist's stance uncharacteristic of analytical writing. ${ }^{16}$ All four texts were published posthumously, insist that the "dignity [of knowledge] is maintained by works of utility and power" [Lat. dignitas scientiae utilitatibus et operibus munitur] (Letters and Life 3.86; Works 6.448), and deploy the same three-stage institutionalizing narrative:

1) Working in the solitude of his studio, the founding philosopher conceives, by virtue of his very genius, a guiding idea, which he alternately calls his "machine" [Lat. machina] and his "fetus" [Lat. foetus] (Works 6.449; 7.58).

2) This guiding idea or program of reform is defined negatively in contrast to the reigning philosophies and institutional constraints that undermine the practice of science, and which are severely criticized. Thus, in The Masculine Birth and The Refutation Bacon dismisses Plato and Aristotle as mere "sophists" because their respective philosophies were not supported by a "serious study and observation of natural phenomena." Aristotle is called the "Anti-Christ," because in order to enthrone himself he attempted to destroy the name and doctrine of his "father[s]," the Presocratics, while Plato is demoted to the condition of a "swelling poet" and a "mocking wit" (Farrington The Philosophy 111, 113, 64).

3) The instituting idea (the "fetus" or "machine") is entrusted to a select group of pupils, to whom the genius delegates the task of keeping alive the institutionalizing process, that is, of inducing the "birth of time" or "setting the machine on work" (Works 6.449; Letters and Life 3.86). ${ }^{17}$

This three-stage path remains insufficient as a legitimating strategy in that it does not theorize the repositioning of the philosophers from the margins of society (the officer of state's private studio) to the centers of power. Of equal importance is the fact that it does not seek to find points of agreement with established discourses or practices, choosing instead to indict indiscriminately the whole Platonic-Aristotelian tradition in an almost apocalyptic tone. ${ }^{18}$ In effect, in the pseudo-autobiographies, in the posthumously published Valerius Terminus, or the Interpretation of Nature (written in 1603), and in his commentary on ancient Greek fables, Of the Wisdom of the Ancients [De sapientia veterum] (publ. 1609), Bacon makes frequent use of the oracular stance and of Presocratic aphorisms. This retreat into open-ended interpretation and away from theory suggests both his interest in dislodging the Platonic-Aristotelian paradigm and his inability to produce 
in the early stages of his career an institutionalizing narrative that could be granted the desired legitimacy. ${ }^{19}$

This first narrative overlaps chronologically during a four-year period with Bacon's earliest attempts to implement his reforms from above, which began during his tenure under James I as King's Counselor (appointed in 1604) and Solicitor General (appointed in 1607). Thus, in Of the Advancement of Learning (1605), Bacon repeatedly apostrophizes James, constructing him as the wisest of all monarchs, and insisting that the "works or acts of merit toward learning" are "opera basilica," a royal task fit only for the mind of the English Solomon (Works 6.180).

The near-synchronicity of Bacon's first and second narratives of institutionalizing (one started from below and the other from above) reveals that, while after James I's accession he certainly did not relinquish his anti-Aristotelian biases, he at least was beginning to envision the Instauration of the sciences as an enterprise that might be of interest to a monarch who fervently desired to make Scholasticism compatible with civil and practical learning (Willson 198-99). Bacon appears in Of the Advancement not as James' appointed counselor in judicial matters (which is what he actually was as King's Counsel), but as his self-appointed delegate in legislating a new science. By assuming the non-existent office of university reformer in the public and ritual act of the dedication, Bacon began to practice what could perhaps be called the performative dimension of royal (self)investiture.

As he continued to ascend the ranks of the apparatchik, Bacon recast his unpublished shorter pieces into the compendious treatise on method, The New Organon, and its companion piece on the historiography of science and the division of intellectual labor, the Paresceve, both published in a single volume in 1620. As he had done in Of the Advancement, in the preface and dedication that precede The New Organon he also invokes the fatherly authority of monarch and God. ${ }^{20}$

A crucial passage for understanding the complex interrelation of the first two narratives is to be found in the 1607 Thoughts and Conclusions:

He [Bacon] proposed a work on the interpretation of nature and on nature itself, designed to eradicate errors with the least possible offence and thus to effect a peaceable entry into the apprehensions of men. This, he thought, should be all the easier, since he did not propose to put himself forward as a leader or guide, but to elicit and spread light from nature herself, thus precluding for the future the need of a leader [Lat. ut duce postea non sit opus]. (Farrington The Philosophy 100; Works 7.141)

The work in question mentioned at the beginning of this passage is in all likelihood The New Organon, whose writing was postponed until 1620. What needs to be emphasized here is that by 1607 Bacon already knew what his research method would be like, and in fact Thoughts and Conclusions contains the first exposition of Bacon's proposed inductive method, the Interpretation of Nature. ${ }^{21}$ At the same time, however, this method was not yet presented in a fashion that could "effect a peaceable entry into the apprehensions of men." On the contrary, Bacon's earliest writings, had they been published immediately after they were written, would have antagonized a great section of his potential audience because of 
their disrespect for the authority of Aristotle and the Scholastics and their lack of a patron, either civil or ecclesiastical. The publication of The New Organon marked a complete reversal of this pragmatic situation, since it happened when Bacon was at the height of his influence as Lord Chancellor and could therefore address James I as the authority who had commissioned the work (which in actual fact was not the case).

In a contiguous passage from Thoughts and Conclusions Bacon elaborates on the paradox that while his task is almost unrealizable, it is prompted by a sense of urgency:

Meanwhile time was passing; he was himself immersed beyond his wish in civil business; and when he thought on the uncertainty of life, delay became unbearable. He felt the need to secure at least some part of his plan, and decided to put forward a simpler statement, which, though not published, might yet suffice to prevent the miscarriage [Lat. abortum] of a thing so wholesome. (The Philosophy 100; Works 7.141)

The "simpler statement" expounding "at least part of his plan" for reforming learning can be reconstructed through a joint reading of the four short autobiographies. Note that Bacon writes Thoughts and Conclusions in 1607, two years after he published Of the Advancement, and that he does not even mention the longer treatise in the autobiography. In 1607 , the year of his appointment as Solicitor-General, he still asserts that the unpublished writings are the ones that represent his "plan" more faithfully. In other words, the great treatises by which Bacon is known as the first utilitarian philosopher of science-Of the Advancement and The New Organon-recast in more acceptable terms the convictions that he voices without censorship in the posthumously published autobiographies.

To recapitulate the differences outlined thus far: the first institutionalizing narrative is predicated on a thorough rejection of Scholastic-Aristotelianism, denies the legitimacy of civil or ecclesiastical authorities in the study of empirical truths, and commends the success of the project to the uncertain care of posterity, which is hypostatized in the persons of the "Sons" or disciples. ${ }^{22}$ By contrast, the second narrative uses Aristotle as an authority, increases the number of citations from Old Testament books (only sparingly used in the earlier texts), abides by the authority of king and church, and insists that the Instauration is a feasible project so long as it is sponsored by a legitimate monarch such as James I-the proposed reforms are opera basilica.

In the dedications of the treatises pertaining to the second narrative of institutionalizing, Bacon seeks royal patronage by explaining to James that knowledge is produced by means of a patrilinear succession (God delegates to James, who delegates to Bacon), and that the kind of learning generated therein simply reflects the "perfect" knowledge possessed by James, who carries "a fountain of learning in himself" (6.90). ${ }^{23}$ Yet the treatise dedicated to James, The New Organon, advocates a form of critical legitimation that quite simply contradicts the idealism implicit in the description of James' mind: "The intellect is not qualified to judge except by means of induction, and induction in its legitimate form" (Works 8.45). "Induction in its legitimate form" denotes the workings of the Interpretation of Nature, a phrase which in turn designates both Bacon's 
master method of research and the process by which the method is put into practice at successive stages by a group of scientists.

This is not how legitimation praxis functioned in early seventeenth-century England. On the contrary, it thrived on the appeal to tradition rather than to rational empiricism. Murray illustrates this point by citing John Bullokar's An English Expositor: Teaching the Interpretation of the Hardest Words (London, 1616) as an instance of what legitimate interpretation meant at the time, i.e., anything "lawfull, lawfully begotten" (Murray 8). Bullokar's phrasing limits the lawful begetting of an idea or a practice to its generation according to a preconceived, unalterable pattern, as does Hooker's above-mentioned notion of "lawful power by the immediate appointment of God."

Even if Bacon should shy away from the antagonizing world of The Refutation, he would still lack the legitimating power of tradition: "I do not endeavor ... by triumphs of confutation, or pleadings of antiquity, or assumption of authority, or even by the veil of obscurity, to invest these inventions of mine with any majesty" (Works 8.34). What Bacon claims to have developed in The New Organon is a rational method, which he defines as a "legitimate, chaste, and severe course of inquiry" (8.52). Chastity and severity are transformed into repression in a contiguous passage: "I interpose everywhere admonitions and scruples and cautions, with a religious care to eject, repress, and, as it were, exorcise every kind of phantasm" (8.50). Commenting upon this very passage, Murray argues persuasively that the "Baconian enterprise of critical legitimation" becomes "compromise[d]" by Bacon's "passionate prescriptions of ejection and repression," and that here the rhetoric of legitimation functions alternately as the "forces of repression" and as the "phantasm that evades the critical exorcisms of the new scientist" (Murray 9). In other words, the legitima Naturae Interpretatio, in order to become institutionalized, needs to hide its own contingent nature behind the guise of necessity. ${ }^{24}$

Murray stresses the repressive strain in Bacon's institutionalizing path as presented in the prefaces to The New Organon. This rhetorical movement toward containment can be easily traced in all three versions of the narrative. As I explained above, in the first version it takes the form of a marriage and a testament that establish respectively a law of generation and a law of succession. These two contracts cooperate in bringing about an uninterrupted line of anonymous intellectual heroes.

In summary, in the second institutionalizing narrative the Interpretation of Nature produces a type of critical legitimation that nevertheless remains insufficient to guarantee the success of the institutionalizing process. As a result, Bacon allows the purity of critical legitimation to become contaminated by other strategies of legitimation that range from divine and royal imposition to a state-sponsored discipline.

The third narrative of institutionalizing, the one deployed in the New Atlantis, proposes a compromise between the first two. In Bacon's last work, the institutionalizing path does not originate in a genius working in isolation (as in the pseudo-autobiographies), but neither is it subjected to the will of a monarch and his court and church (as in Of the Advancement). Instead, the New Atlantis features a fatherly king who voluntarily withdraws from the political world by establishing a technocratic foundation to whose members he delegates his civil power. The members of Salomon's House are called Fathers and his disciples Sons, by analogy with other patrilinear orders existing in 
Bensalem, which they either predate (Christianity) or consciously emulate (the extended family of the Tirsan or clan's patriarch and the now-ornamental monarchy).

In the nation of Bensalem an enlightened and benign despot, Solamona, arranges for his own succession and for the aristocracy of blood to step down from executive positions of power. At the same time he invests a newly created order of epistemocrats with quasiabsolutist prerogatives in the issuing of institutional policy, both domestic and foreign. Bensalem thus provides an inverted reflection for the England Bacon aspired to reform: a nation where each Christian form of observance (Protestant, Catholic, and Puritan) still functioned in addition as a rite of varying social and political legitimation; where the fatherly first Stuart King dreamed of carrying out his own fantasy of a personal rule; ${ }^{25}$ where non-Aristotelian philosophy was rendered suspect due to its association with atomism, religious sorcery, and even low drudgery; ${ }^{26}$ and where types of experimentally based science were often not easily reconciled with the respective dogmas of "divines," "politiques," and "learned men themselves" (Of the Advancement [Works 6.91]). ${ }^{27}$ In fact, to argue for the realization of God's kingdom on earth (as suggested by the teachings of Moses, Solomon, and Daniel) was tantamount to declaring onself a Puritan (Hill 110-12). The paradox that Solomon (and in general Old Testament prophecy) could at the same time serve the interests of Protestants, religious radicals, and secular scientists was the result of an interpretive ambiguity: whereas James and his court eulogists interpret Solomon's proverbial knowledge as the moral wisdom that divine providence bestows conservatively upon peaceful and lawful kings, Bacon construes it as the knowledge of second causes that will allow humankind to control change in the natural world. ${ }^{28}$

Clearly, then, Bacon's legitimating rhetoric must aim at the reconciliation of theology with natural philosophy, of Theorica with Practica, and of the Catholic with the Protestant dogma. In the New Atlantis such a reconciliation takes the form of a historicist utopian narrative in which a seventeenth-century non-European nation is presented that did not experience any of the schisms just mentioned. Two features of Bensalem's institutional history in particular relate to this specific conflict of authorities: first, the temporal anteriority of experimental science in relation to abstract thought and Christianity determined that the Bensalemites had neither a Plato or Aristotle nor an Augustine or Aquinas; and second, a personal decision of King Solamona institutionalized the cultivation of mechanical philosophy and natural history, and minimized the political responsibilities of his royal successors and their courts (by disengaging Bensalem from world history). The very structuring of the New Atlantis as a series of three first-person accounts dealing, respectively, with the Europeans' inability to control nature (this is how I read the mariner's account of the near-shipwreck with which the work begins), with the course of Bensalem's political history, and with the organization of Salomon's House, suggests Bacon's faith in the achievability of a truly utilitarian commonwealth. What is more, his use of both historicism and the autoptic or eye-witness stance point to a underlying authorial strategy aimed to hide the frictions and contradictions inherent in process of historial change. ${ }^{29}$

There is no description in the New Atlantis of Bensalem's practice of an institutionalized religious worship prior to the Father's interpretation of the supernatural apparition in Renfusa. The Fathers themselves had no religion, and practiced a 
predominantly materialist and utilitarian brand of natural philosophy. After the initial gesture of delegation by Solamona, they appear to have maintained their legitimacy among the non-Fathers in the truly Baconian way, "by works of utility and power." The programmatic status of this principle becomes apparent in the central statement contained in the Father's relation: "The End of our Foundation is the knowledge of Causes, and secret motions of things; and the enlarging of the bounds of Human Empire, to the effecting of all things possible"' (Works 5.398). Here the word "empire" does not describe the perpetuation of a colonial situation in which the group occupying the geographical center of an economic and social system dictates the destiny of the groups occupying the margins. Rather, it denotes the emancipation of human life from the tyranny of physical affliction. ${ }^{30}$ For Bacon, humankind has always enjoyed the "sovereignty of all inferior creatures," and so any kind of knowledge that contributes to increasing the human "power and dominion" over nature is legitimate so long as it is immediately "referred to use and action" rather than "contemplation" (Valerius Terminus [Works 6.28-29]). ${ }^{3 !}$ This dominion goes as far back as Moses and Solomon, the two Old Testament champions of material progress, both of whom play a crucial part in the New Atlantis. ${ }^{32}$ As Blumenberg writes, in Bacon "a concept of human happiness appeared that separated theory from existential fulfillment by reducing the necessary knowledge to the amount fixed by the requirements of domination over natural reality" $(239) .^{33}$

\section{Conclusion: Bacon, James I, and the Solomonic Experiment.}

Since I have argued that the position of originator of the institutionalizing process is occupied alternately by Bacon (in the first version of the narrative) and James I (in the second version), it is only fitting that I should conclude this essay by suggesting the way Bacon may have desired James to read the New Atlantis. In the dedication part of The Advancement James had been construed as the English Solomon on the basis that his person embodied the "triplicity" of "king," "priest," and "philosopher" (Works 3.88, 90). ${ }^{34}$ Because these are also Solamona's offices, the Bensalemite king can be considered both a type of James and an anti-type or successor of the biblical Solomon. Solamona had responded to Bensalem's need for a strong legislator who could create a new consensus and ensure its future preservation.

The experience of reading Bacon's own foundational fiction - the New Atlantis--was to provide James I with specific instructions on how to fulfill, in his own self-proclaimed role as proverbial Rex pacificus of the Protestant world, the Solomonic destiny to which he felt called. Bacon hails James as the subject and agent of his own Solomonic instauration in three different ways. First, as head of both Church and State, James has the power to realize the Danielesque prophecy of a coming Golden Age of scientific exploration-the works of the Instauration are opera basilica, as Bacon writes in Of the Advancement and the Paresceve. ${ }^{35}$ Second, like Solomon and Solamona, James can literally monumentalize his name in the stone of a temple of science-the stone, that is, of another Salomon's House. Perhaps even more importantly, by both industrial and spiritual works James can also control the historical destiny of his own succession. Bacon 
expressed his concern about the imminence of a bloody religious revolution in the fourpage Preface, a text which ironically remained unpublished until after the Caroline Restoration. Read in conjunction with the account of Solamona's achievements, the Preface offers a set of instructions as how to preclude a regicide in the Stuart dynasty, and along the way, it also proposes a substitute for monarchical power by arguing for the empowerment of a new class of college-educated epistemocrats. For Solamona's descendants seem to have survived and multiplied all the way up to the seventeenth century, even though their court remains cut off from public business and their names are not even mentioned in any of the numerous narrative threads that make the New Atlantis.

Similarly, when in the first institutionalizing narrative Bacon addresses the scientists of the future, he offers them the same gift of continuity in exchange for the erasure of their names from the text of the future. They must pay with their own names for the survival of their lineage. Bacon's "beatissima proles Heroum" (The Masculine Birth [Works 7.31]) is a lineage of anonymous subjects living outside of epic history, which in Bensalem was given closure by ancient Solamona, and in England might perhaps be cancelled out by James, "thus precluding for the future the need of a leader" (Thoughts and Conclusions [Farrington The Philosophy 100]).

From the very first narrative it is quite clear that the goal of Bacon's distancing from Aristotelianism is not the unconditional release of critical interpretation. In all three versions of the narrative, as Bacon's method and reform plans become institutionalized, they attempt to drive all their opponents from the field of interpretation. Aristotle's dictatorship is thus replaced by Bacon's method, which he compares to a "Spartan testament" [Lat. haereditas Spartana] because it is designed to "equalize men's wits and faculties" (The Refutation [Farrington The Philosophy 118; Works 7.77]) ${ }^{36}$ This proposed Spartan discipline will leave all his successors letter-bound, that is, enslaved to the letter of the law. ${ }^{37}$ Bacon's philosophy of science is an emphatically patriarchal institution designed to reproduce endlessly not only the desired alterations of natural phenomena, but also a rigid hierarchy of producers and consumers of learning. ${ }^{38}$ Patriarchal structures characterize Bacon's projected methods for both acquiring new knowledge and safely transmitting it. The question of whether Bacon liked patriarchy may well lack a definite answer. What seems indisputable, however, is that the type of critical thinking he advocates in the first narrative challenges the primacy of abstract theoretical and philological learning over experimentation. It also threatens the monopoly of science kept by patriarchal institutions such as the Protestant Church and the universities.

The main question to be asked in the light of Bacon's proto-Enlightenment perspective is as follows: could he have presented critical legitimation in a radically diferent way, that is to say, uncontaminated by the same discourses that it aimed to dislodge in the first place? It would be difficult to argue that he could, since the legitimation of either a new praxis or a new discourse in early-seventeenth-century England required a favorable climate of opinion, which in turn could be best induced by invoking the more recognizable patriarchal authorities of God and monarch.

The greatest paradox built into Bacon's efforts to legitimate his reform plans and implement the new institutions of science lies in the presentation of his interpretive machine enveloped in organicist metaphors. On the one hand, Bacon voices his analytical 
and empiricist imperatives in statements such as "the dignity of knowledge is maintained by works of utility" (Preface) and "the intellect can only judge by means of induction in its legitimate form" (The New Organon). On the other hand, however, this program of critical legitimation is ultimately deflated by Bacon's unremitting recourse to patrilinearity. If the organization of science is like the organization of the family, and the production of works like filial procreation, then a commonwealth, in order to perpetuate itself, only needs to strengthen the institutions of the family and its existing patrilinear correlatives. This emphasis suited very well the conservative philosophy of government upheld by James I, who in Bacon's long and flattering dedications and apostrophes could only see yet another testimony of his own Solomonic stature.

\section{Notes}

1. Among the most useful short accounts of Bacon's project of critical interpretation are Daston; Reiss, especially chs. 5 and 6; and Blumenberg, especially. ch. 7 of Part I and Intro. to Part III. Some of the ideas found in Blumenberg and Reiss are summarized in Bender \& Wellbery 6-8. For the political implications of the proposed new interpretive machine, see ch. 3 of Hill; and Farrington Francis Bacon.

2. This point is made in Habermas 10. Despite its intended applicability to exclusively latecapitalist societies, Habermas' treatment of legitimation parallels Bourdieu's. Thus, for instance, Habermas stresses that the speech acts of legitimation transform the "subjectivity of opinion" of an elite group into general interests; Bourdieu that they represent primarily the elite group that pronounces them, whether this is composed of priests, government technocrats, or aspiring scientists. Habermas warns that what is "general" is often perceived as "objective"; Bourdieu that socially accepted realities become in time "natural" ones. Finally, both stress the role of linguistic utterances in creating, fulfilling, or transforming the "expectations" (Habermas) or "habitus" (Bourdieu) of an audience.

3. See Works Cited for complete references. For similar groups in a broad European context, see Mandrou; and Grafton. Pocock makes the same argument for specifically religious dissenters who occupied positions of responsibility in the English administrative system on the eve of the Civil War: "the English saint was not radically alienated from the secular order, but on the contrary radically involved in it ... The crucial moment will be that at which God's Englishman, having initially believed that his nation was elect of the intensity of his involvement in its institutions, comes to believe that some or all of these institutions are unworthy of the work to which the nation is elect" (346-47; emphasis in the original). Lastly, on an individual's simultaneous membership in two or more mutually conflicting intellectual and political groups, see Roots.

4. For the earliest occurrences of these two revealing phrases, see respectively the Preface for the unwritten De Interpretatione Naturae (Letters and Life 3.87; Works 6.449) and The Refutation of Philosophies (Farrington The Philosophy 114; Works 7.71). Throughout this essay, whenever two parenthetical page references are given at the end of a quotation or a paraphrase from Bacon, the first one refers to the English version of a Latin text and the second one to the Latin original.

5.See in this connection Giddens' gloss on Georg Simmel's definition of "trust" as "weak inductive knowledge," a situation (says Giddens) "in which the confidence vested in probable 
outcomes expresses a commitment to something rather than just a cognitive understanding" (2627).

6. I use "hegemony" in the sense employed by McLellan, who in turn dwells on Gramsci's adaptation from Lenin and Lukács. A dominant social group becomes hegemonic when it ceases to "struggle for its own narrow interests" to construe itself publicly as "the representative of the interests of society as a whole" (31).

7. Here Bacon seems to echo Plato's concern (in The Republic, the Statesman, and the Laws) with finding a self-evident form of demonstration capable of defeating both persuasion and argument (the orator and the politician's weapons), and consequently of supporting the philosopher's claim to the highest form of authority. On this Platonic argument, see Arendt 10409. Arendt uses the term "authority" in the sense Bacon uses "legitimacy," to denote the preHegelian principle of peaceful coercion by which one free individual affects the decisions and actions of another with the two of them being aware of both their mutual freedom to choose and the relation of subjection built into the consensus between them.

8. This concern corresponds to what White calls "Baconian charity" (21).

9. The argument deployed in the preceding two paragraphs is meant to indicate that my understanding of Baconian legitimation departs from Reiss' notion of Baconian "legitimacy." As Reiss' choice of word shows, he is more interested in the acquired legitimate status of a method and a discourse than in the institutonalizing process from which that legitimacy emerges. Noting the many occurrences of the word "legitimus" in Bacon's earlier short pieces, Reiss argues that for Bacon "[1] egitimacy' has to do both with truth as an adequation of words, concepts, and things (that is, with correspondence - or reference), and with the logical system capable of rendering such adequation (that is with coherence-or analysis)" (220).

10. The consideration of king, governor, and father as essentially interchangeable offices resurfaces in James I's 1597 Trew Law of Free Monarchies (Political Works 55). Willson notes the King's admiration for Hooker's great work (199).

11. Pocock, in ch. 3 of The Machiavellian Moment, presents a magisterial account of the uses of prophecy in Renaissance Italy to promote the creation of a secular regime based upon preChristian notions of utilitas and the vita activa. For instances of a similar prophetic rhetoric being used by both the dominating and the dominated groups coexisting in the same political space, see Zagorin 140-71.

12. For Bourdieu, the social regime based primarily on patrilinearity, which he calls "patriarchalism," is founded on an undeclared paradox: "by a permanent denial of self-interest, [it] transforms the relation of domination into an enchanted relation" (Language 128). A very useful account of patriarchy in seventeenth-century England appears in Schochet, especially 37-98. More recently Goldberg has defined "patriarchalism" as "a regular feature of family life in which the natural event of procreation becomes an extension of male prerogative and male power" ("Fatherly Authority" 16).

13. In addition to the Old Testament prophet and philosopher, we find three Solomonic kings in Bacon's writings: Henry VII, who had to overcome great odds in order to institute the Tudor dynasty (Works 11.354); James I, whose claim to Solomonic stature I discuss below; and Solamona, the Bensalemite king who established a New Atlantis by delegating his power to a caste of utilitarian scientists (New Atlantis [Works 5.380-83). White discusses the relation of Bacon's History of the Reign of Henry VII to his attempts to fashion James as the first English Solomon to become interested in natural philosophy (see ch. 4 of his book). For an overview of the various topoi of natural philosophy, political wisdom, and religious leadership that converge on the figure of Solomon, see Conway. 
14. Thomas Elyot had celebrated Solomon as the proverbial Rex pacificus in a well-known passage from The Governor (1531), under the section heading "Of sapience, and the definition thereof" (218-21). A letter of 1606 by John Harrington describes in detail the conceit staged at court in honor of the Danish King, and which consisted in "the representation of Solomon's Temple and the coming of the Queen of Sheba" (39).

15. Minnis explains how in the thirteenth and fourteenth centuries (thanks largely to the exegetical efforts of Bonaventure and of the Oxford Dominican, Robert Holcot) Solomon emerged as the auctor or engenderer of wisdom, and by extension of all sapiential books written by his posterity (94-96). See also Arendt's important distinction (which she attributes to Pliny) between auctor-the inspirer of a large-scale enterprise-and artifex-the actual builder or composer of a thing (122). On James' fantasy of becoming the driving force of England's literary tradition (in fact, its auctor), see Goldberg James I 17-27.

16.In one of these pieces, Thoughts and Conclusions, the autobiographical voice is articulated in a more impersonal way by using the passive voice in a discourse that nevertheless conveys the "thoughts" and "resolutions" of a passionate philosopher.

17. For a reading that complements my own, emphasizing the generation of a "new universe of discourse" rather than the consensus between master and pupil, see Reiss 221-22. More recently, the master-pupil relationship in The Masculine Birth has been construed along homoerotic lines by Hammill (243-45).

18. Farrington has summarized the reasons behind Bacon's aversion to classical Greek philosophy. His hostility toward Aristotle "has two sources, the corruption of Christian doctrine by metaphysics and the corruption of science by a logic fertile in arguments but barren of useful arts. Bacon is not attempting a sober estimate of an historical figure. It is a living influence which he attacks" (Farrington The Philosophy 35). As for (Neo)Platonism, it failed to provide manual laborers and commoners in general with a sense of active participation in the advancement of the commonwealth; on the contrary, it simply "supplied the elite of wealth and birth with the ideal of an aristocratic type of state and with an aristocratic culture" (The Philosophy 35).

19. White was the first scholar to note Bacon's abhorrence of the Greek notion of theoria and his corresponding embracement of a Hebraicizing notion of interpretatio (20-21). Two recent philosophical assessments of this polarity are to be found in Rosen 147, 162; and Atkins 43-48, 53-55.

20. A letter from James I thanking Bacon for his dedication of The New Organon in 1620 shows that the King had understood Bacon's request (in Of the Advancement and in New Organon) that new "seats and places of learning" or research apparatuses be endowed by the Crown (Works 6.173). Thus, in his letter James feels momentarily compelled to assert that he "will give a due commendation to such places as in [his] opinion shall deserve it" (Letters 375). There is no record of such a commendation. Furthermore, in his biography of James, Willson gives several examples of the King's habit of promising endowments and other forms of patronage to various institutions, and of forgetting those commitments just as frequently.

21. Bacon worked on different versions of the Interpretation of Nature (on a strictly theoretical basis) from the very beginning of his writing career, and produced a total of four formulations, in Thoughts and Conclusions (Farrington The Philosophy 98-100; Works 7.138-40), Valerius Terminus (6.43-44), The New Organon (8.135-39), and New Atlantis (5.409-11). For a devastating and erudite critique of some important shortcomings of Bacon's method that rendered it inadequate to produce a scientific revolution, see Jardine 147-49. A more sympathetic account appears in Cohen, who states that "Bacon revolutionized the philosophy of science, but he certainly did not produce a Baconian revolution in science" (150). 
22. The ideologue's refusal to subject himself to the judgment of his contemporaries, choosing instead the verdict of posterity is an acknowledged feature of the Enlightenment ethos (Becker 140-43).

23. Bacon goes on to say that he hopes he "may excite [his] princely cogitations to visit the excellent treasure of [his] own mind, and thence to extract particulars agreeable to [his] magnanimity and wisdom" (Works 6.91). The "purpose" is specified in the same paragraph as "the advancement of learning." "Advancement" could not possibly be understood by James as meaning reform, since the contents of his mind are here posited as being already complete and flawless.

24. This sentence is indebted to Godzich's brilliant discussion of how an emerging institution tends to repress its origin as an accepted yet arbitrary deviation from an earlier institution.

25. "[F]atherly authoritie" is James I' own phrase in Basilikon Doron (Political Works 4), where he characteristically equates his biological paternity (the work is addressed to his first-born, Prince Charles) with his royal prerogative. Goldberg notes that "in the preface to Basilikon Doron [James] wrote as if from the grave, declaring that his book was his last will and testament" ("Fatherly Authority" 12). Both Bacon and James conceived of themselves as auctores in the Solomonic sense of someone who engenders wisdom with a view to instituting a genealogy of wise men.

26.See Quinton 83-84. Hill notes that the contemporaries who shared some of Bacon's ideas also amounted to "a list of the leaders of the opposition in the Long Parliament" (99).

27. This claim is supported by Le Goff 159-63; and Kearney 80-88. For the contrary argument, see Grafton 1-5. For the polarity of Theorica and Practica, see Berger 92-94.

28. The locus classicus of Solomon's excessive love of wordly pleasures appears in Book III of Augustine's On Christian Doctrine 97-98. Ginzburg provides a good discussion of the two meanings alternately attributed to the Greek epistème and the Latin sapere in biblical exegesis.

29.This procedure corresponds to what Bourdieu calls the "sovereign viewpoint," which substitutes the "observer's relation to practice for the practical relation to practice," thus inducing an effect of "totalization" (The Logic of Practice 27, 34, 86). Pagden uses the Aristotelian category, "autoptic," to denote the "I"/eye-witness stance that we often find in early modern philosophical and judicial texts, and in narratives of conquest and exploration. The autoptic enunciator disengages himself from the weight of custom or tradition that imposes on him certain interpretive constraints, choosing instead to rely on what he claims is his first-hand experience (5153).

30. See Blumenberg 105-07. Knapp, in his authoritative survey of English Renaissance fictions of empire, explains that Bacon's references to the enterprise of America do not argue for nor against a specific imperial policy, and therefore do not suggest that Bacon was as interested in colonial expansion as he was in scientific discovery (245-48). The contrary view is held by Martin, who goes so far as to claim that Bacon's reformed natural philosophy was but a means toward his "passion and great project" for establishing "an imperial Britain" (135). Two instances of a one-sided reduction of Baconian science to a project of subjection and surveillance appear in Horkheimer \& Adorno 3-8; and in ch. 5 of Archer.

31. My reading of this passage is indebted to Blumenberg 386-87. An earlier version of Bacon's argument appears in Meditationes Sacrae (1597), where he makes his famous statement, "knowledge itself is power" [Lat. ipsa scientia potestas est] (Works 14.95; 79). In both works contemplation is equated with heresy, as if to emphasize Bacon's awareness that his project may be construed by some as subversive of the extant religious orthodoxy. 
32. Auerbach has discussed the problematics involved in the early Christian readings of Old Testament prophecies as promises of material comfort as well as Augustine's efforts to sublimate them into promises of spiritual salvation (39-42).

33. The same idea appears in Blumenberg 106. There he also argues that the seventeenthcentury concept of progress did not result from the secularization of a Christian eschatology, but rather was deeply rooted in pagan Greek and Roman philosophy. For the contrary view, specifically within the English context, see Hill 93.

34. In the Epistle Dedicatory of The New Organon Bacon tells James I that he "resembles Solomon in so many things - in the gravity of [his] judgments, in the peacefulness of [his] reign [and] in the noble variety of the books which [he has] composed" (Works 8.23).

35. Bacon paraphrases Daniel's prophecy of discovery (as is enunciated in Daniel 12.4) in Valerius Terminus, The Refutation, and The New Organon (Works 6.32; 7.93; 1.304-05). English translations of the pertinent passages in the last two works appear in Farrington The Philosophy 131-32; and Works 8.130.

36. Similarly, in Valerius Terminus Bacon claims that "the course of interpretation now propounded ... doth in fact equal men's wits" (Works 6.73).

37. In the Discourse on Method (1637), Descartes uses the metaphor of the Spartan legislation to argue, like Machiavelli and Bacon, that the laws drawn up by a single legislator, "tend[ing] toward the same end," are more suitable for a utilitarian regime (88). In The Discourses (1517; publ. 1531), Machiavelli writes that "though one man alone is fit for founding a government, what he has founded will not last long if it rests upon his shoulders alone; it is lasting when it is left to the care of many and when many desire to maintain it" (201).

38. Theorists of the institutionalizing process agree on singling out "reproduction" as a crucial function developed by institutions in order to ensure their own perpetuation (Bourdieu 137-38; Godzich 157).

\section{Works Cited}

Archer, John Michael. Sovereignty and Surveillance: Spying and Court Culture in the English Renaissance. Stanford: Stanford UP, 1993.

Arendt, Hannah. "What Is Authority?" Between Past and Future: Eight Exercises in Political Thought. Rev. ed. New York: Penguin, 1977. 91-141.

Atkins, G. Douglas. Reading Deconstruction/ Deconstructive Reading. Lexington: UP of Kentucky, 1983.

Auerbach, Erich. "Figura." Scenes from the Drama of European Literature: Six Essays. New York: Meridian, 1959. 11-76.

[Saint] Augustine. On Christian Doctrine. Trans. D.W. Robertson, Jr. Indianapolis: Bobbs-Merrill, 1958.

Bacon, Francis. The Letters and the Life of Francis Bacon Including All His Occasional Works.

7 vols. Ed. James Spedding. London: Longmans, 1861-74. .The Works of Francis Bacon. 15 vols. Ed. James Spedding, Robert Leslie Ellis, and Douglas Denon Heath. Boston: Brown, 1861.

Becker, Carl L. The Heavenly City of the Eighteenth-Century Philosophers. New Haven: Yale UP, 1968.

Bender, John, and David E. Wellbery. "Rhetoricality: On the Modernist Return to Rhetoric." The Ends of Rhetoric: History, Theory, Practice. Ed. Bender and Wellbery. Stanford: Stanford UP, 1990. 3-39. 
Berger, Harry, Jr. Second World and Green World: Studies in Renaissance Fiction-Making. Berkeley: U of California P, 1988.

Blumenberg, Hans. The Legitimacy of the Modern Age. 1966. Trans. Robert M. Wallace. Cambridge, MA: MIT P, 1982.

Bourdieu, Pierre. Language and Symbolic Power. Trans. Gino Raymond and Matthew Adamson. Ed. John B. Thompson. Cambridge, MA: Harvard UP, 1991. . The Logic of Practice. Trans. Richard Nice. Stanford: Stanford UP, 1990.

Cohen, I. Bernard. Revolution in Science. Cambridge, MA: Belknap P of Harvard UP, 1985. Conway, Moncure Daniel. Solomon and Solomonic Literature. New York: Haskell, 1973.

Curtis, Mark H. "The Alienated Intellectuals of Early Stuart England." Crisis in Europe, 15601660. Ed. Trevor Aston. Garden City, NY: Doubleday, 1967. 309-31.

Daston, Lorraine. "Baconian Facts, Academic Civility, and the Prehistory of Objectivity." Annals of Scholarship 8 (1991): 337-64.

Descartes, René. The Philosophical Works of Descartes. Trans. and ed. Elizabeth S. Haldane and G.R.T. Ross. Vol. 1. Cambridge: Cambridge UP, 1967.

Elyot, Thomas. The Book Named the Governor. 1531. Ed. S.E. Lehmberg. London: Dent, 1962. Farrington, Benjamin. Francis Bacon: Philosopher of Industrial Science. New York: Collier, 1961.

The Philosophy of Francis Bacon: An Essay on Its Development from 1603 to 1609 with New Translations of Fundamental Texts. Chicago: U of Chicago P, 1966.

Ginzburg, Carlo. "High and Low: The Theme of Forbidden Knowledge in the Sixteenth and Seventeenth Centuries." Past and Present 73 (1976): 28-41.

Godzich, Wlad. "Afterword: Religion, the State, and Post(al) Modernism." Institution and Interpretation. By Samuel Weber. Minneapolis: U of Minnesota P, 1987. 153-64.

Goldberg, Jonathan. "Fatherly Authority: The Politics of Stuart Family Images." Rewriting the Renaissance: The Discourses of Sexual Difference in Early Modern Europe. Ed. Margaret W. Ferguson, Maureen Quilligan, and Nancy Vickers. Chicago: U of Chicago P, 1986. 3-32. James I and the Politics of Literature: Jonson, Shakespeare, Donne, and Their Contemporaries. 1983. Stanford: Stanford UP, 1989.

Grafton, Anthony. Defenders of the Text: The Traditions of Scholarship in an Age of Science, 1480-1800. Cambridge, MA: Harvard UP, 1991.

Habermas, Jürgen. Legitimation Crisis. Trans. Thomas McCarthy. Boston: Beacon P, 1973. Hammill, Graham. "The Epistemology of Expurgation: Bacon and The Masculine Birth of Time." Queering the Renaissance. Ed. Jonathan Goldberg. Durham, NC: Duke UP, 1994. 236-52.

Harrington, John. "James I and the King of Denmark (from a Letter Dated 1606)." The Renaissance in England. Ed. J.V. Cunningham. New York: Harcourt, 1966. 39-41.

Hill, Christopher. The Intellectual Origins of the English Revolution. Rev. ed. Oxford: Clarendon P, 1982.

Hooker, Richard. Of the Laws of Ecclesiastical Polity. Vol. 1: Books I-IV. 1593. Ed. Christopher Morris. London: Dent, 1967.

Horkheimer, Max, and Theodor W. Adorno. Dialectic of Enlightenment. 1944. Trans. John Cumming. New York: Seabury P, 1977.

James I. Letters of James VI \& I. Ed. G.P.V. Akrigg. Berkeley: U of California P, 1984. The Political Works of James I. Ed. Charles H. McIlwain. Cambridge, MA: Harvard UP, 1918.

Jardine, Lisa. Francis Bacon and the Art of Discourse. Cambridge: Cambridge UP, 1974. Kargon, Robert. Atomism in England from Hariot to Newton. Oxford: Clarendon P, 1966. 
Kearney, Hugh. Science and Change, 1500-1700. New York: MacGraw-Hill, 1971.

Knapp, Jeffrey. An Empire Nowhere: England, America, and Literature from Utopia to The Tempest. Berkeley: U of California P, 1992.

Le Goff, Jacques. Intellectuals in the Middle Ages. Trans. Teresa Lavender Fagan. Cambridge, MA: Blackwell, 1993.

Machiavelli, Niccolò. The Portable Machiavelli. Trans. and ed. Peter Bondanella and Mark Musa. Baltimore: Penguin, 1982.

Mandrou, Robert. From Humanism to Science 1480-1700. Trans. Brian Pearce. Harmondsworth: Penguin, 1978.

Martin, Julian. Francis Bacon, the State, and the Reform of Natural Philosophy. Cambridge: Cambridge UP, 1992.

McLellan, David. Ideology. Minneapolis: U of Minnesota P, 1986.

Minnis, A.J. Medieval Theory of Authorship: Scholastic Literary Attitudes in the Later Middle Ages. 2nd ed. Philadelphia: U of Pennsylvania P, 1988.

Murray, Timothy. Theatrical Legitimation: Allegories of Genius in Seventeenth-Century England and France. New York: Oxford UP, 1987.

Pagden, Anthony. European Encounters with the New World: From Renaissance to Romanticism. New Haven: Yale UP, 1993.

Pocock, J.G.A. The Machiavellian Moment: Florentine Political Thought and the Atlantic Republican Tradition. Princeton: Princeton UP, 1975.

Quinton, Anthony. Francis Bacon. New York: Oxford UP, 1980.

Reiss, Timothy. The Discourse of Modernism. Ithaca: Cornell UP, 1982.

Roots, Ivan. "Interest--Public, Private and Communal." The English Civil War and After, 16421658. Ed. R.H. Parry. Berkeley: U of California P, 1970. 111-22.

Rosen, Stanley. Hermeneutics as Politics. New York: Oxford UP, 1987.

Schochet, Gordon J. Patriarchalism and Political Thought: The Authoritarian Family and Political Speculations and Attitudes Especially in Seventeenth-Century England. New York: Basic, 1975.

White, Howard B. Peace among the Willows: The Political Philosophy of Francis Bacon. The Hague: Martinus Nijhoff, 1968.

Willson, David Harris. King James VI \& I. New York: Oxford UP, 1967.

Zagorin, Perez. Societies, States, and Early Modern Revolution: Agrarian and Urban Rebellions. Vol. 1 of Rebels and Rulers, 1500-1660.2 vols. New York: Cambridge UP, 1982. 